\title{
Developing And Implementing A Social Media Program While Optimizing Return On Investment - An MBA Program Case Study
}

\author{
David M. Gilfoil, Ph.D., DeSales University, USA \\ Steven M. Aukers, Ph.D., DeSales University, USA \\ Charles G. Jobs, Ph.D., DeSales University, USA
}

\begin{abstract}
Over the past decade, Web 2.0 has brought a wealth of opportunities for improving marketing effectiveness; social media platforms, in particular, have proven to be exceptional tools for realizing growth potential. The big question for businesses used to be how to measure and report financial return on investment (ROI) for social media ad spend to show that it is impactful as a marketing media tool. The focus has now shifted to how much traditional media spend should be reallocated to social or online media. The current paper is a Social Media case study of a large MBA program which has developed and implemented a comprehensive Social Media program with a focus on two "ROI" issues - financial Return on Investment and Reallocation of Investment. Social media plan development and implementation, integrated marketing/sales funnel development, and social media platform ROI results are discussed and evaluated. Lessons learned and next steps are also posited.
\end{abstract}

Keywords: Social Media; Return On Investment (ROI); Reallocation Of Investment; Social Selling; Marketing And Sales Funnel; Full Funnel Analytics; Advertising Analytics; Big Data; Web 2.0; MBA Program Case Study

\section{INTRODUCTION}

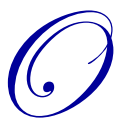

ver the past decade, Web 2.0 has brought a wealth of opportunities for improving marketing effectiveness; social media platforms, in particular, have proven to be exceptional tools for realizing growth potential. Historically, the big question for businesses used to be how to measure and report financial return on investment (ROI) for social media ad spend to show that it is impactful as a marketing media tool. Considerable progress has been made understanding and measuring ROI with the help of technological advances (i.e. QR codes, landing pages, tags) and of course, an explosion of mobile users and a corresponding explosion of mobile apps. The focus has now shifted to how much marketing spend should be reallocated from traditional to social media and online vehicles.

The current paper is a Social Media case study of a large, private MBA program in Northeast Pennsylvania which, over the past 13 years, has advertised via radio, billboard, print, and other traditional media. Within the past 18 months, the program has developed and implemented a comprehensive and integrative Social Media plan with a central focus on two ROI issues - how to definitively measure financial Return on (ad) Investment and how to optimally engage in a Reallocation of (ad) Investment to achieve cost-effective market growth. The case study's Social Media plan centers around a comprehensive social media framework including a mission statement, social media goals, key personnel roles and responsibilities, an integrated marketing/sales funnel processes, and select social media platforms. Preliminary ROI results are discussed and evaluated by social media platform, while lessons learned and next steps are also posited. 


\section{LITERATURE REVIEW}

Social Media (SM) platforms have been studied over the last 5-7 years because of their tremendous potential for global business enhancement (Piskorski and McCall, 2010; Van der Lans, Van Bruggen, Eliashberg, and Wierenga, 2010). Much literature exists, for example, in the usage of Web 2.0 and social media platforms in electronic word of mouth advertising (Jansen, Zhang, Sobel and Chowdry, 2009; Jalilvand, Esfanani, and Samiei, 2011) and viral marketing (Leskovec, Adamic, and Huberman, 2007; Hartline, Mirrokni, and Sundararajan, 2008). Constantinides, Romero, and Boria (2008), as well as Jobs (2012), and Gilfoil and Jobs (2011) have further studied the use of SM platforms for global buy and sell activities and have provided anecdotal evidence of seemingly successful corporate usage of SM platforms to engage user communities, prospects, and end customers in both active and passive ways. From the consumers' perspective, survey data from the Gartner Group, reported that $74 \%$ percent of consumers rely (to some degree) on social networks to guide their purchase decisions (Gartner, 2010). Social media usage clearly caught on by the 2009-2010 timeframe, but questions remained about whether or not it was truly effective. Corporate and institutional marketing executives wanted proof that social media ad spend would pay off by driving top line revenues.

\section{Return On Investment}

In the past five years, Social Media Return on Investment (ROI) has been further discussed and debated in trade publications, corporate and consumer blogs, and a host of professional publications (Bartholomew, 2009, 2010; Fisher, 2009; Murdough, 2009; Arnold and Solis, 2011; Nair, 2011; Ray, 2010; Solis, 2008, 2010). Several books have also been written on the topic (i.e. Blanchard, 2011; Powell, Groves, and Dimos, 2011; Kelly, 2012). From this body of work (and much more like it), Social Media ROI began to be viewed as a key requirement for validating the success of SM marketing and management programs - although some practitioner surveys suggested that measuring ROI was still a primary challenge for $57 \%$ of marketers (eMarketer, 2012) and that only $12 \%$ of companies were able to track the effectiveness of their social media efforts against revenues (Awareness, 2012).

Gilfoil and Jobs (2012) provided a detailed review of the SM ROI literature - detailing a vast range of opinions, models, and calculations in both academic and trade journals. From this literature, they proposed a "3D unit of analysis" framework for better understanding the inherent complexity of measuring social media - and provided numerous examples (at multiple organizational levels) to construct their model. They also discussed SM ROI measurement within the context of business process/performance management basics and suggested guidelines and principles for how and when to proceed with such measurement. One of the key takeaways from Gilfoil and Jobs (2012) was that there appeared to be limited circumstances where social media projects/campaigns could directly and immediately be evaluated in terms of traditional, financial ROI.

\section{Reallocation Of Investment}

More recently, Jobs and Gilfoil (2014) have built upon the premise of the 3D Unit of Analysis Framework and reconciled that social media, as a promotional channel, is more complex than traditional media, and may even be more critical to a firm's success down the road. They also suggested, based on the pioneering work of Nielsen \& IAB (2012), that strategic organizations should not evaluate social media return as an activity independent of traditional media. Instead, companies should gain competitive advantage and improve their financial ROI through a reallocation of advertising investment - a portion of monies spent on traditional media (e.g. TV, radio, billboards) should be shifted to social and other online media (e.g. LinkedIn, Facebook, Twitter, Pandora). Jobs and Gilfoil (2014) provided an overview of the literature justifying the need for this reallocation approach and even proposed an adaptation of Rogers Innovation Adoption Curve (Rogers, 2003) to help understand the likely path of current/future ad budget reallocation rates - loosely based on industry, customer base, job function, and a host of other factors. The authors suggested that the reallocation of investment approach could yield measurable advertising cost efficiencies for companies in the short term while they continue to think about how to merge traditional and social media activities into effective integrated marketing communications programs in the long run. 


\section{Advertising Analytics And Big Data}

Wes Nichols recently published an article in the Harvard Business Review which introduced, to many, the term Advertising Analytics 2.0 (Nichols, 2013). Driven by complex computer algorithms and fueled by streams of traditional and digital media measurement data, Advertising Analytics 2.0 allows for real-time "company-centric" algorithms for understanding and tweaking traditional/digital advertising mix elements for maximum effectiveness. Advertising analytics, together with the more generic field of "big data" - which involves data driven discovery and decision making (Lohr, 2012; McAfee, et al, 2012) - are currently being utilized by top marketing analytics firms (i.e. Adometry, C3Metrics, Convertro, Marketshare and Visual IQ) to help companies attribute marketing success to the right media, optimize the right timing and ad mix, and finally allocate marketing resources more effectively.

In most businesses, the impact of advertisements across each channel (print, television, online, etc.) is measured independently. Nichols (2013) calls this "swim-lane" measurement. This type of measurement ignores the role played by advertisement in other channels. Done properly, Advertising Analytics, according to Nichols, depicts the assisted effects of each new channel added to the marketing communications mix already in play. Nichols further states that the effect of advertising on consumer behavior and business results is based on variables related to market conditions, marketing actions and competitive activities. Advertising analytics involves the processing of terabytes of data simultaneously and instantaneously. In sum, it helps advertisers make important decisions for optimal investment in the right channels and measures how effective these combinations are in influencing the customer to purchase goods or services.

\section{Marketing/Sales Funnels And Social Selling}

Table 1. Marketing/Sales Funnel Activities And Metrics By Funnel Segment

\begin{tabular}{|c|c|c|c|}
\hline \multicolumn{4}{|c|}{ Top of Funnel (Acquisition/Brand Awareness) } \\
\hline Objectives & Content & Media/Platforms & Metrics \\
\hline $\begin{array}{ll}\text { - } & \text { Generate Leads } \\
\text { - } & \text { Brand Awareness } \\
\text { - } & \text { Generate web traffic }\end{array}$ & $\begin{array}{ll}\text { - } & \text { Value Proposition } \\
\text { - } & \text { Articles } \\
\text { - } & \text { Press Releases } \\
\text { - } & \text { Advertorials } \\
\text { - } & \text { Display ads }\end{array}$ & $\begin{array}{ll}\text { - } & \text { Billboards } \\
\text { - } & \text { Radio/Pandora } \\
\text { - } & \text { LinkedIn } \\
\text { - } & \text { Facebook } \\
\text { - } & \text { Twitter } \\
\end{array}$ & $\begin{array}{ll}\text { - } & \text { Impressions } \\
\text { - } & \text { Clicks } \\
\text { - } & \text { Web traffic } \\
\text { - } & \text { Share of voice }\end{array}$ \\
\hline \multicolumn{4}{|c|}{ Middle of Funnel (Engagement) } \\
\hline Objectives & Content & Media/Platforms & Metrics \\
\hline $\begin{array}{ll}- & \text { Generate Prospects } \\
\text { - } & \text { Optimize Search } \\
\text { Ranking } \\
\text { Prospect } \\
\text { Communication } \\
\text { (engagement \& } \\
\text { education) }\end{array}$ & $\begin{array}{ll}\text { - } & \text { Case Studies } \\
\text { - } & \text { White Papers } \\
\text { - } & \text { SEO/SEM } \\
\text { - } & \text { Videos } \\
\text { - } & \text { Reprints } \\
\text { - } & \text { News Updates } \\
\text { - } & \text { Pay Per Click }\end{array}$ & $\begin{array}{ll}\text { - } & \text { Website } \\
\text { - } & \text { Twitter } \\
\text { - } & \text { LinkedIn } \\
\text { - } & \text { Facebook } \\
\text { - } & \text { eMail }\end{array}$ & $\begin{array}{ll}\text { - } & \text { New web visitors } \\
\text { - } & \text { \# web visits } \\
\text { - } & \text { Actions per visitor } \\
\text { - } & \text { SEO/SEM ranking } \\
\text { - } & \text { Pay Per Click }\end{array}$ \\
\hline \multicolumn{4}{|c|}{ Bottom of Funnel (Conversion) } \\
\hline Objectives & Content & Media/Platforms & Metrics \\
\hline $\begin{array}{ll}- & \text { Generate Customers } \\
\text { - } & \text { Sales Conversions } \\
\text { - } & \text { Customer } \\
\text { Communication } \\
\text { (service) }\end{array}$ & $\begin{array}{ll}\text { - } & \text { Webinars } \\
\text { - } & \text { SEO/SEM } \\
\text { - } & \text { Coupons } \\
\text { - } & \text { Consultations } \\
\text { - } & \text { Directions/Maps } \\
\text { - } & \text { Display } \\
\end{array}$ & $\begin{array}{ll} & \text { Website } \\
- & \text { eMail } \\
\text { - } & \text { LinkedIn }\end{array}$ & $\begin{array}{ll}- & \text { \# conversions } \\
\text { - } & \text { Cost per conversion } \\
\text { - } & \text { Revenue }\end{array}$ \\
\hline
\end{tabular}

The discussion around Social Media ROI as measured in financial terms has clearly evolved and has recently been re-cast in the popular literature as bloggers, book authors, and social media pundits have embraced the merits of more closely integrating marketing/sales and have refined the sales funnel concept into multi-level marketing/sales funnels using terms like "full funnel marketing," "full funnel analytics" and "social selling" (Rosenberg, 2013; Keenan, 2013; Viskovich, 2013; Moran, 2014) just to name a few. Many of these authors have, in various forms, differentiated between top of funnel (TOFU), middle of funnel (MOFU), and bottom of funnel 
(BOFU). Table 1 depicts a composite overview of these three (3) level funnels describing key objectives, content, media/platforms and metrics at each level. It is now generally agreed that true financial ROI only occurs at the bottom of the marketing/sales funnel when prospects convert into cash customers through a transaction - in the case of an MBA program, enrolling in class.

\section{CASE STUDY}

DeSales University is a private, Catholic, baccalaureate/graduate institution located in northeast Pennsylvania. The purpose of this case study is to summarize the efforts of DeSales University's MBA program to develop, launch, and manage a comprehensive social media pilot program over an 18 month period. The case study also attempts to:

- Understand and operationalize two return on investment issues - return on investment and reallocation of investment.

- Introduce the concepts of advertising analytics and big data as a backdrop for ultimately achieving the optimal integration of traditional and social media marketing efforts.

- $\quad$ Introduce the concept of a more closely integrated marketing and sales funnel.

- Describe the broader context of typical business and academic challenges in running a large MBA program

The study will outline the flow of the Social Media program, explain the core steps and elements, and identify lessons learned and next steps for continuous improvement.

\section{DeSales MBA Social Media Mission Statement}

"To create vibrant DeSales MBA communities within the social space of the world-wide web that generate engagement and conversion of prospects into registered students, allowing the MBA program to create long-term relationships cultivated through valuable interaction and content sharing" 


\section{Social Media Framework}

The social media framework depicted in Figure 1 was developed, refined, and launched over a three month period with input from select MBA staff and faculty. Each step in the process is briefly described below:

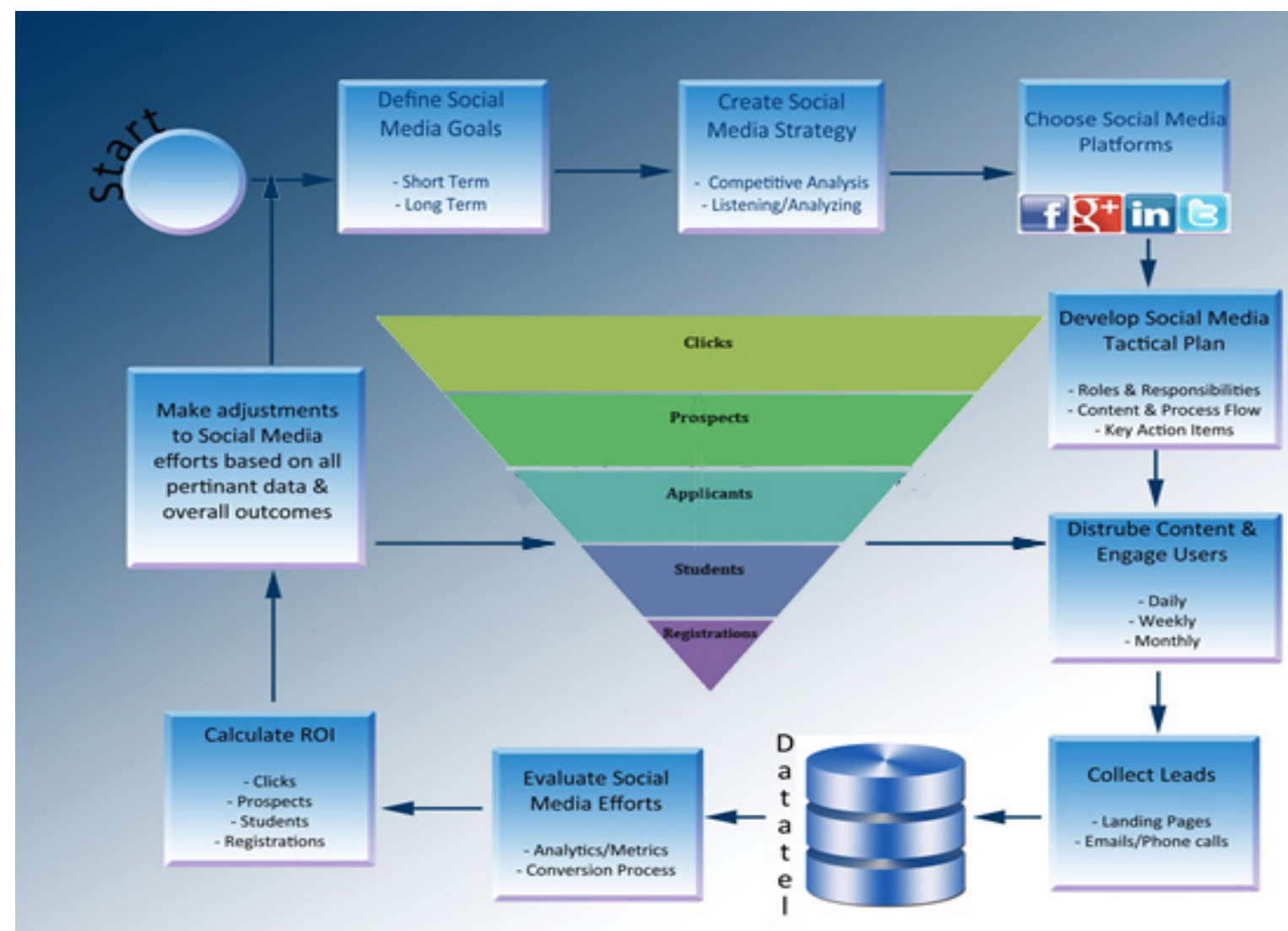

Figure 1. DeSales MBA Social Media Framework

\section{Model Elements/Process Flow}

1. Define Social Media Goals

The DeSales University MBA Program's key Social Media goals are:

- $\quad$ Increase Brand Awareness in key targeted industries and geographic markets.

- $\quad$ Enhance Search Engine Optimization/Marketing (SEO/SEM) rankings.

- $\quad$ Drive increased traffic to the DeSales MBA website.

- Communicate with our (student and corporate) prospects and customers.

- $\quad$ Convert MBA prospects through marketing/sales funnel stages.

- $\quad$ Develop and refine ROI mechanisms for tracking the effectiveness of social media and online adverting.

- $\quad$ Establish and grow DeSales MBA's presence on at least three (3) select social media platforms.

\section{2. $\quad$ Create Social Media Strategy}

The DeSales MBA Social Media strategy was straightforward - conduct a survey with prospective, current, and past MBA students to determine their social media preferences, usage patterns and behaviors (Figure 2). Next, benchmark best-in-class competition to determine which platforms they are using (see Figure 3 for 2012 Facebook 
competitor baseline). Finally, from documented research findings and the teams' knowledge of integrated marketing communication (IMC), develop an integrative approach to using social and online media with other traditional media.

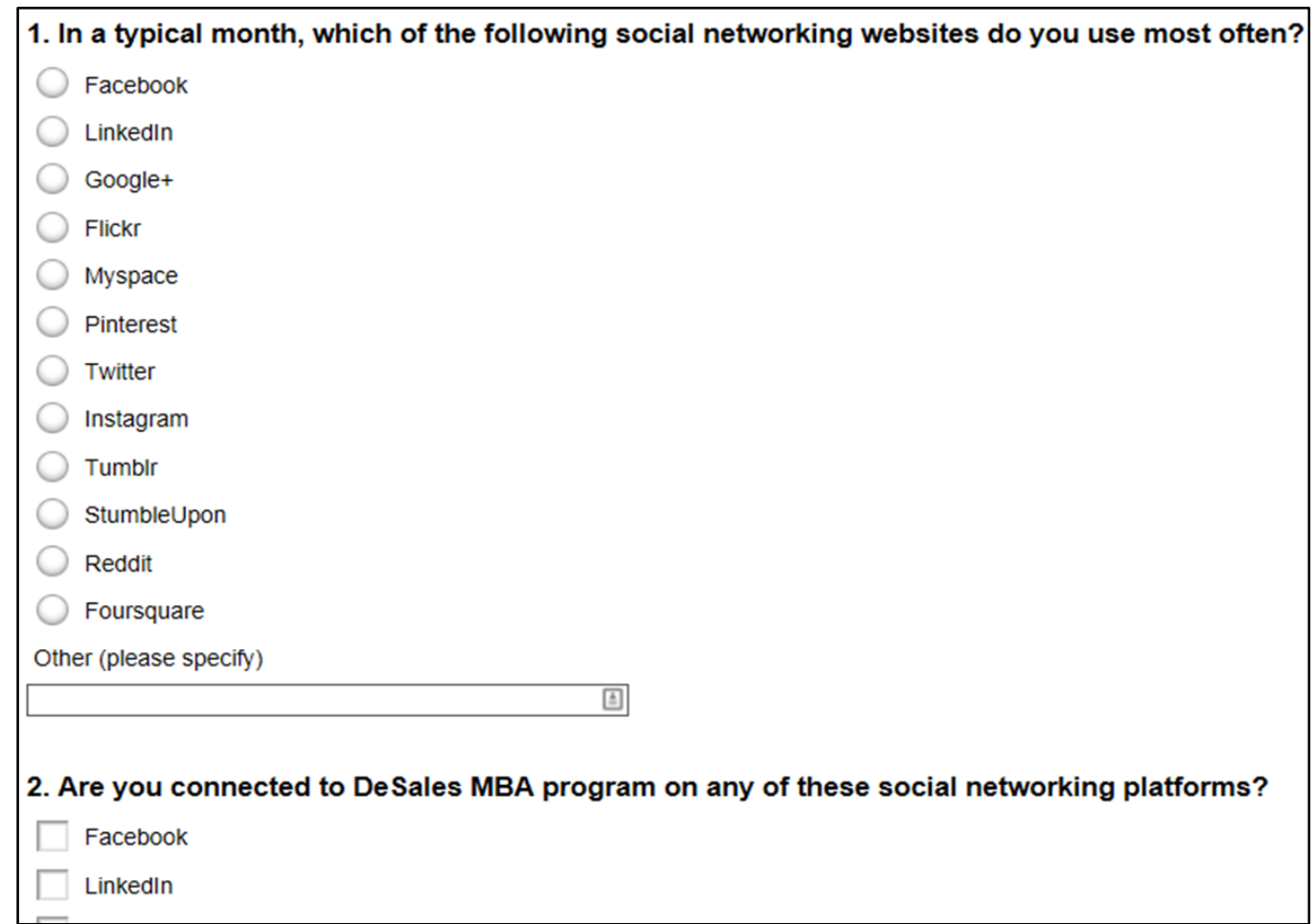

Figure 2. Social Media Survey

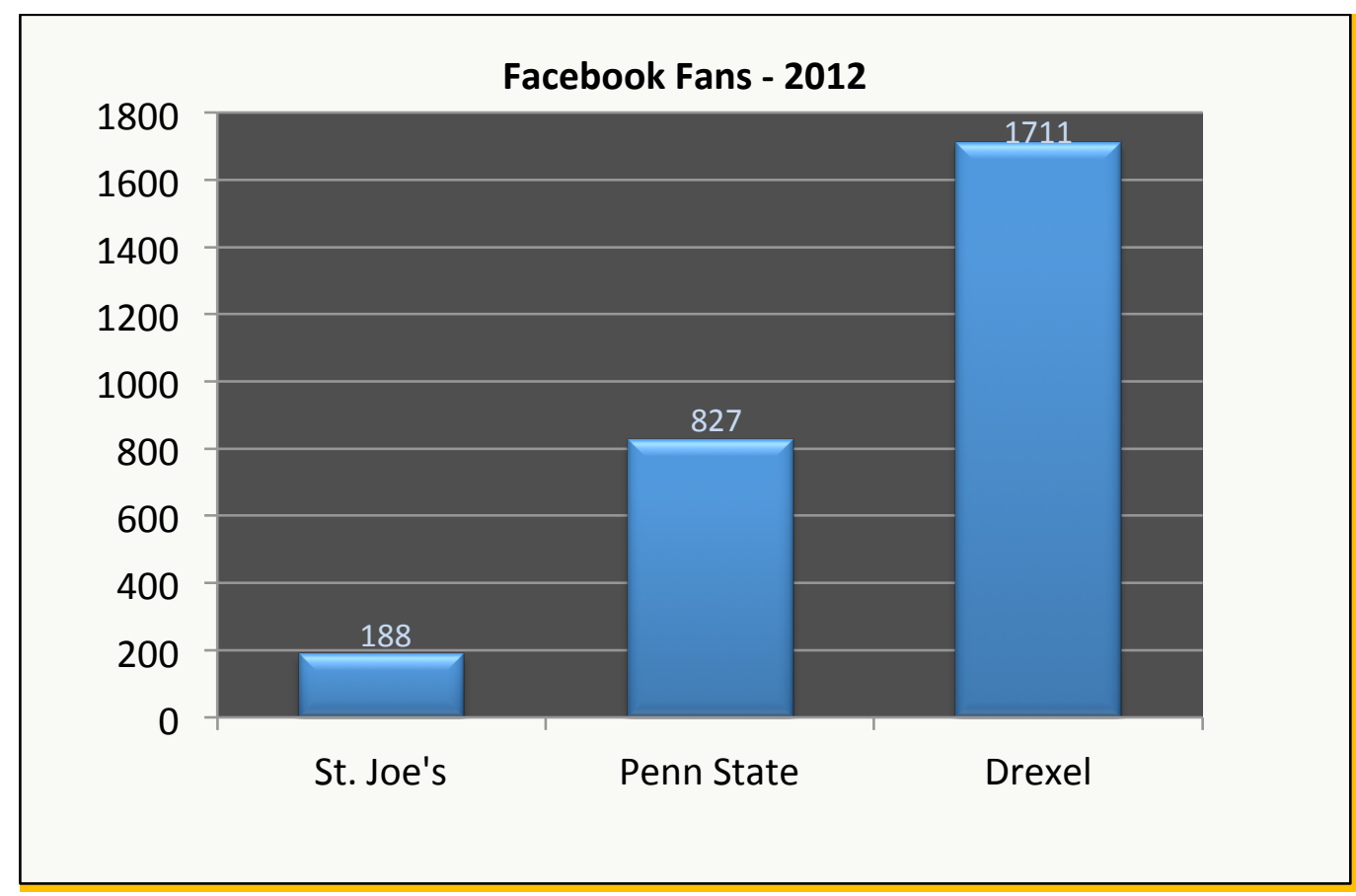

*baseline data was gathered during the Fall 2012 timeframe

Figure 3. Competitor Tracking 2012 - Facebook* 


\section{Select Social Media Platforms}

Data from the survey and competitive analysis in Step 2 helped guide the selection of Facebook, LinkedIn, and Twitter platforms to start. Choices were further validated and additional platforms were added after reviewing the 2012 CMO Guide to the Social Landscape (see Figure 4) which assesses each platform in terms of its utility for Search Engine Optimization (SEO), building MBA brand awareness, communicating with corporate customers/students, and generating traffic to the university website. These criteria were consistent with a subset of the Social Media program goals discussed above.

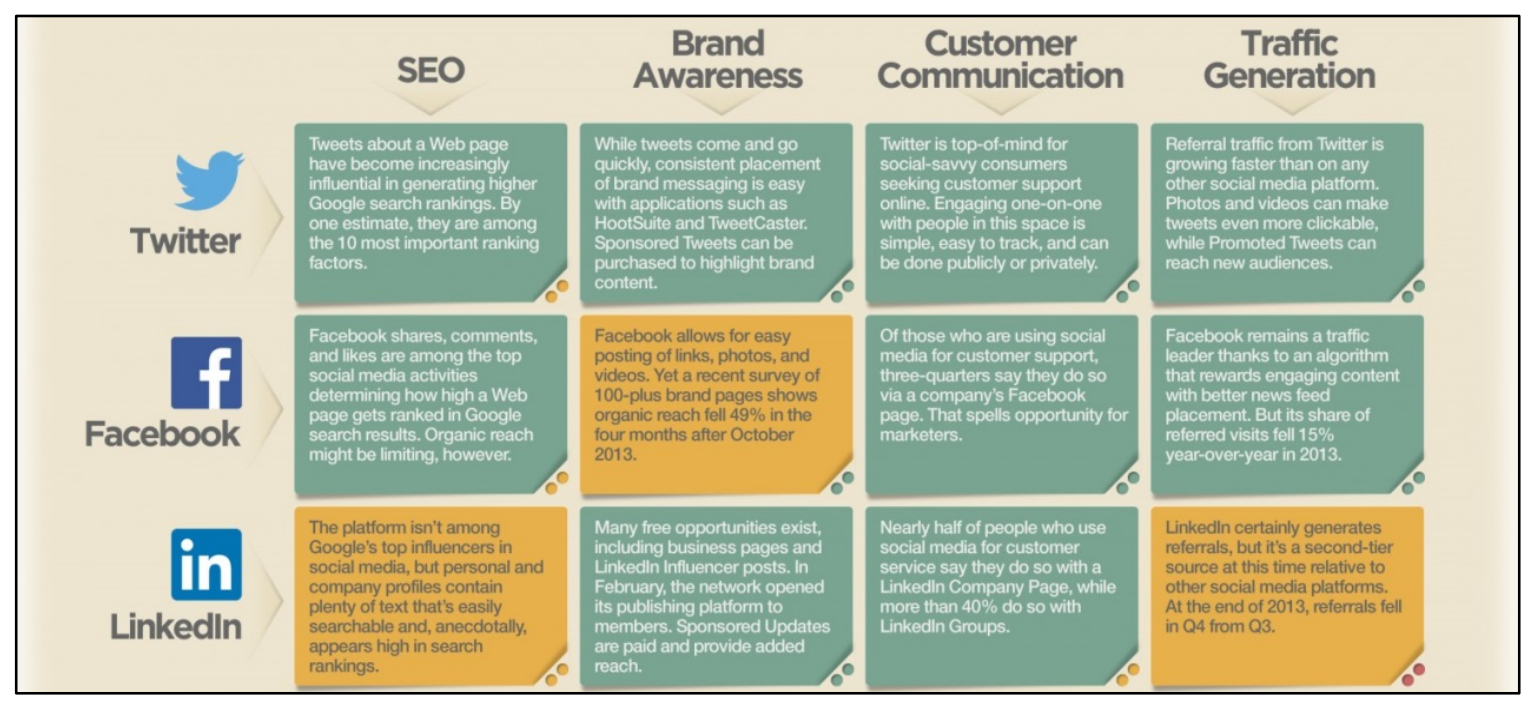

Figure 4. Social Media Platform Selection Criteria - Adopted From CMO Guide

The social media platform assessment was complemented by individual platform overview data depicting highlights, benefits and limitations as they might relate to the MBA program. Data for the LinkedIn platform is shown in Figure 5. Similar overviews were completed for Facebook, Twitter and other platforms (Google+, Instagram) that were considered for incorporation into the Social Media Plan.

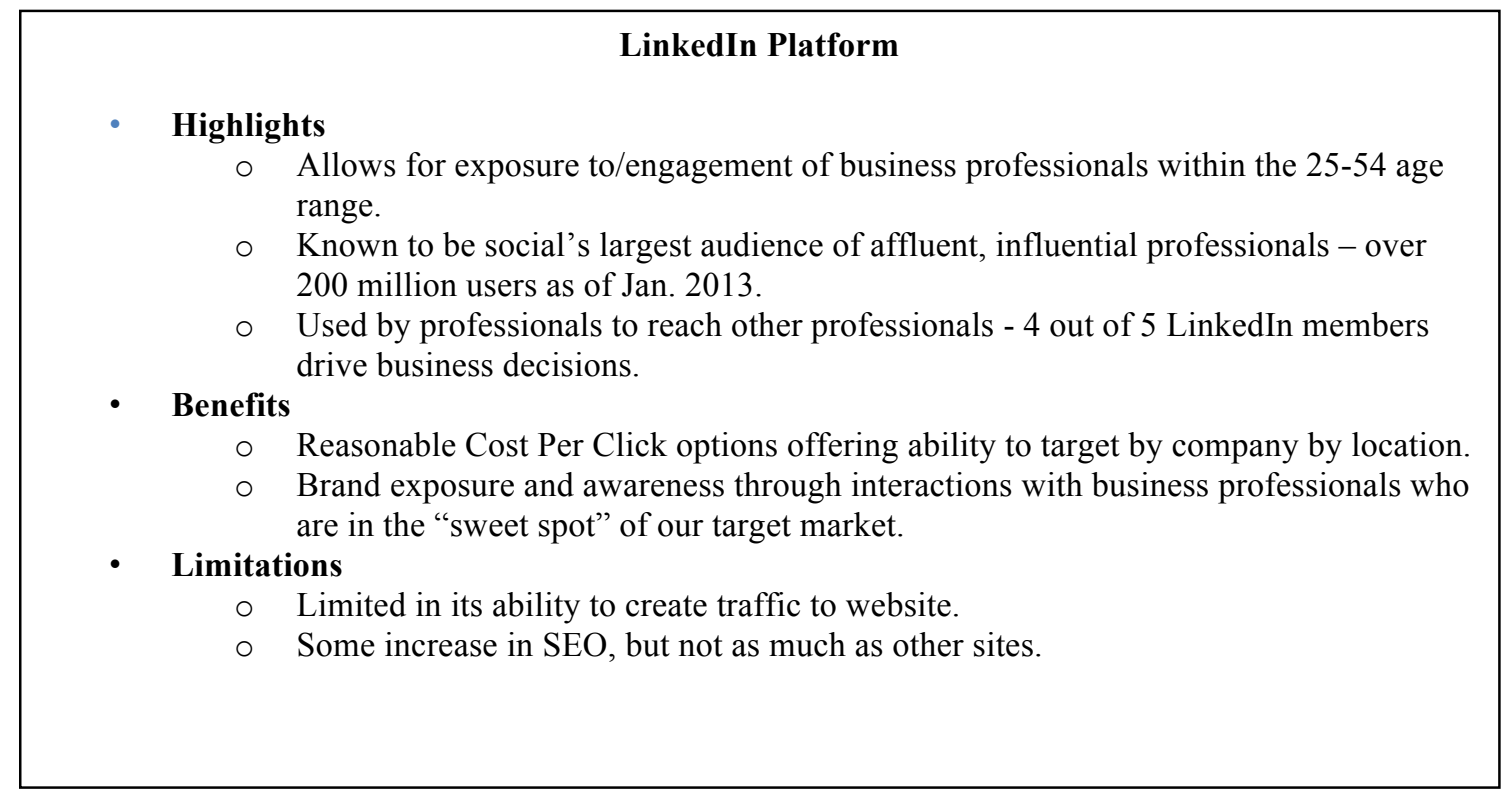

Figure 5. LinkedIn - Platform Highlights, Benefits, Limitations 


\section{Develop Tactical Plan}

The tactical plan for the MBA social media program was centered on people, processes, and content. The MBA Director developed and implemented processes that determined what social media tasks should be grouped and assigned to which individuals, and how these processes and people would focus on the selection, creation and distribution of content relevant to the MBA stakeholders. The necessary functional roles and responsibilities were established to deploy a successful program; those roles and responsibilities were then aligned with the existing MBA staff. To fill the gaps, a part-time consultant was hired who worked 15-20 hours in the capacity of "Social Media Manager.” Roles and responsibilities for key social media positions are shown in Figure 6.

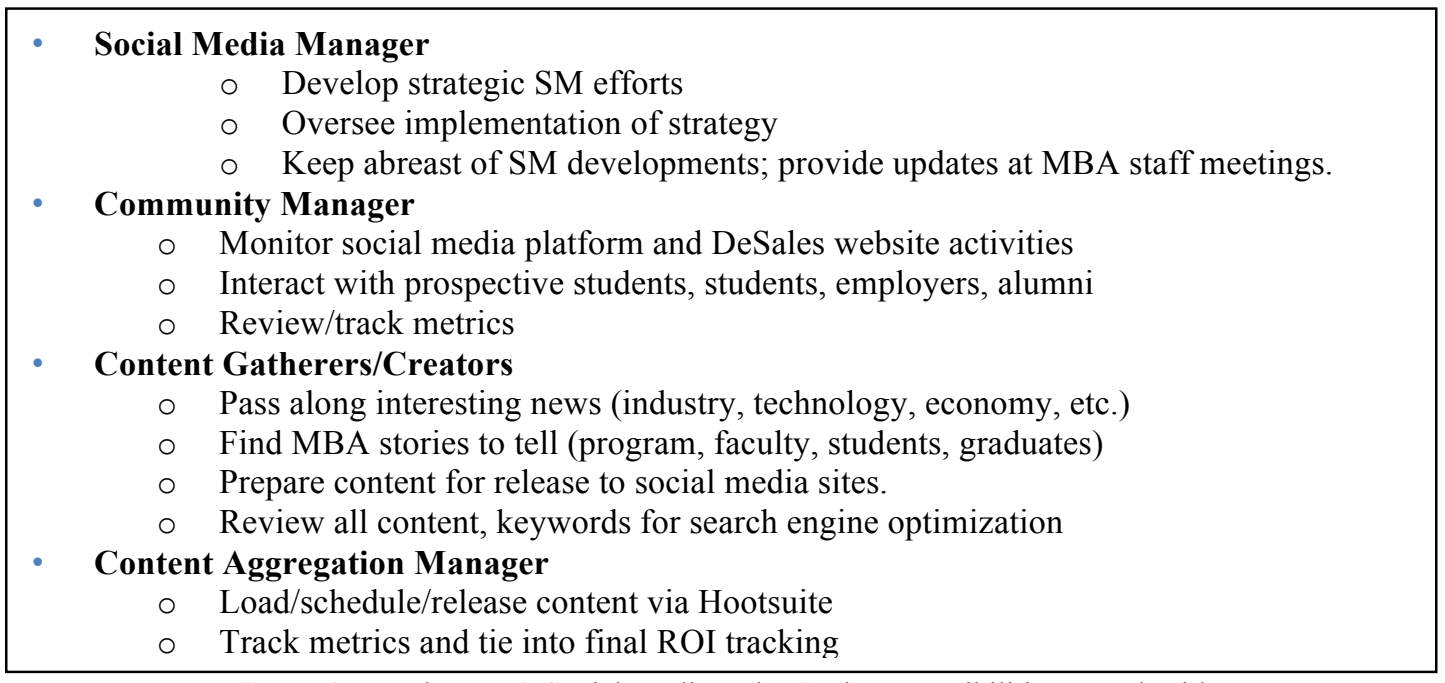

Figure 6. Desales MBA Social Media Roles And Responsibilities By Job Title

Ultimately, the tactical plan spells out who will do what by when to create and distribute social media content, engage prospective and current MBA communities, and to drive traffic to the MBA website for conversion to revenue. Figure 7 depicts the complexity of interactions between the MBA website, social media websites used to share MBA content, other social media websites, and major search engines. It also portrays the geometric "brand lift" that can occur when content gets shared within/among different social media venues. During MBA international practicum trips, for example, DeSales MBA faculty and staff tweet photos and short messages that summarize learnings and global experiences. These tweets go out directly to the MBA "twitter followers," but also get posted on the MBA website, MBA Facebook, and a number of other social media sites. In turn, anyone who is exposed to these tweets can then share the information with people in their social networks. All of this activity gets picked up by Google and other search engines. This, in turn, increases the likelihood of DeSales MBA showing up "top-of-page" in organic search results when certain key words (i.e. Lehigh Valley MBA) are used. Figure 7 also depicts how various kinds of paid advertising (i.e. digital display ads) tie in to this process. In addition, it shows that key prospect, student, or employer data is captured and stored (in Datatel) for further communication and engagement activities - all geared to driving prospects down the marketing/sales funnel towards revenue realization. 


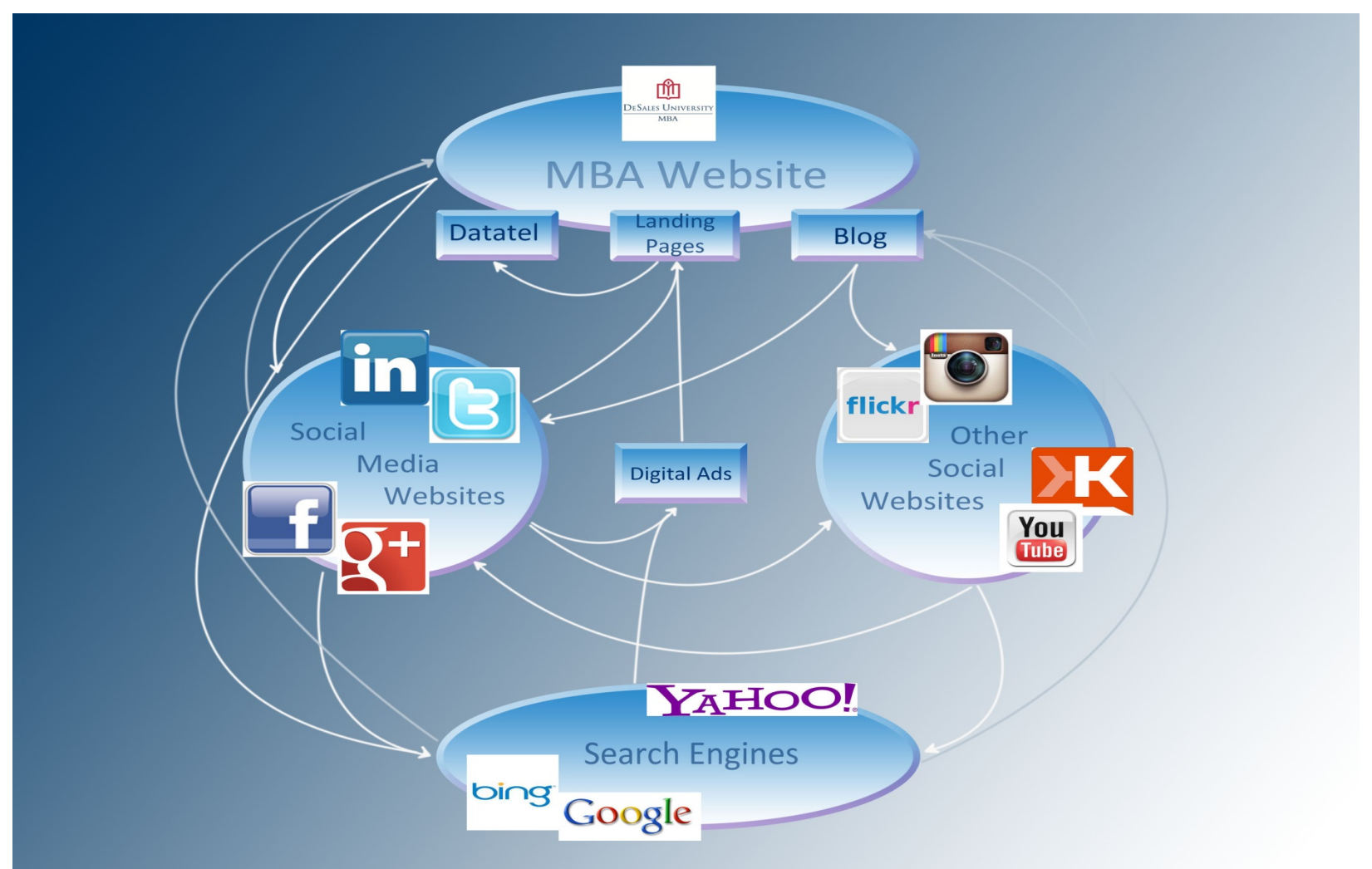

Figure 7. DeSales MBA Social Media Process Flow

\section{5. $\quad$ Develop And Distribute Content And Engagement}

Step 5 is probably one of the most important steps in the entire social media process. It is the step where a provider demonstrates that it can create or forward information that meets the needs, wants, or desires of its target markets. Content, for this discussion, can be defined as any information related to the DeSales MBA program (or its operating environment) that may be of interest or value to an MBA stakeholder (prospect, student, graduate, faculty, employer, community member, etc.). Content can be about an impending or recent MBA event, a recent accomplishment of an adjunct or full-time faculty member, the success of current MBA students or alumni, or a simple community/industry update. The content can highlight any of the value add attributes of the MBA program (i.e. flexible, affordable, practical, multiple venues) validated by current/past students. Content can also come in different formats - blogs, tweets, emails, display ads, photos, videos, pop up ads, or white paper. Daily, weekly, and monthly task activities associated with DeSales MBA content are listed below:

Daily

- $\quad$ Create new content

- $\quad$ Solicit content from stakeholders

- $\quad$ Share existing content (i.e. re-tweets)

- $\quad$ Respond to comments and inquiries from previous posts

- $\quad$ Delete spam; manage flow of conversation

Weekly

- $\quad$ Create tagged URLs for content to enable effectiveness tracking

- Schedule weekly posts (using HootSuite or similar content management system) for optimal target audience reach

- $\quad$ Review weekly activities and generate summary report 
Monthly

- $\quad$ Schedule monthly posts based on impending events and activities in funnel

- $\quad$ Review past month's activities and generate summary report for review at staff meeting

- Make adjustments to social media strategy, platform usage, target markets, content, etc.

An example of a recently developed Facebook display ad for the Northeast PA (Pocono) area is shown in Figure 8. It was targeted at middle income, 25-45 year old professional individuals who live or work close to the satellite DeSales Pocono area campus.

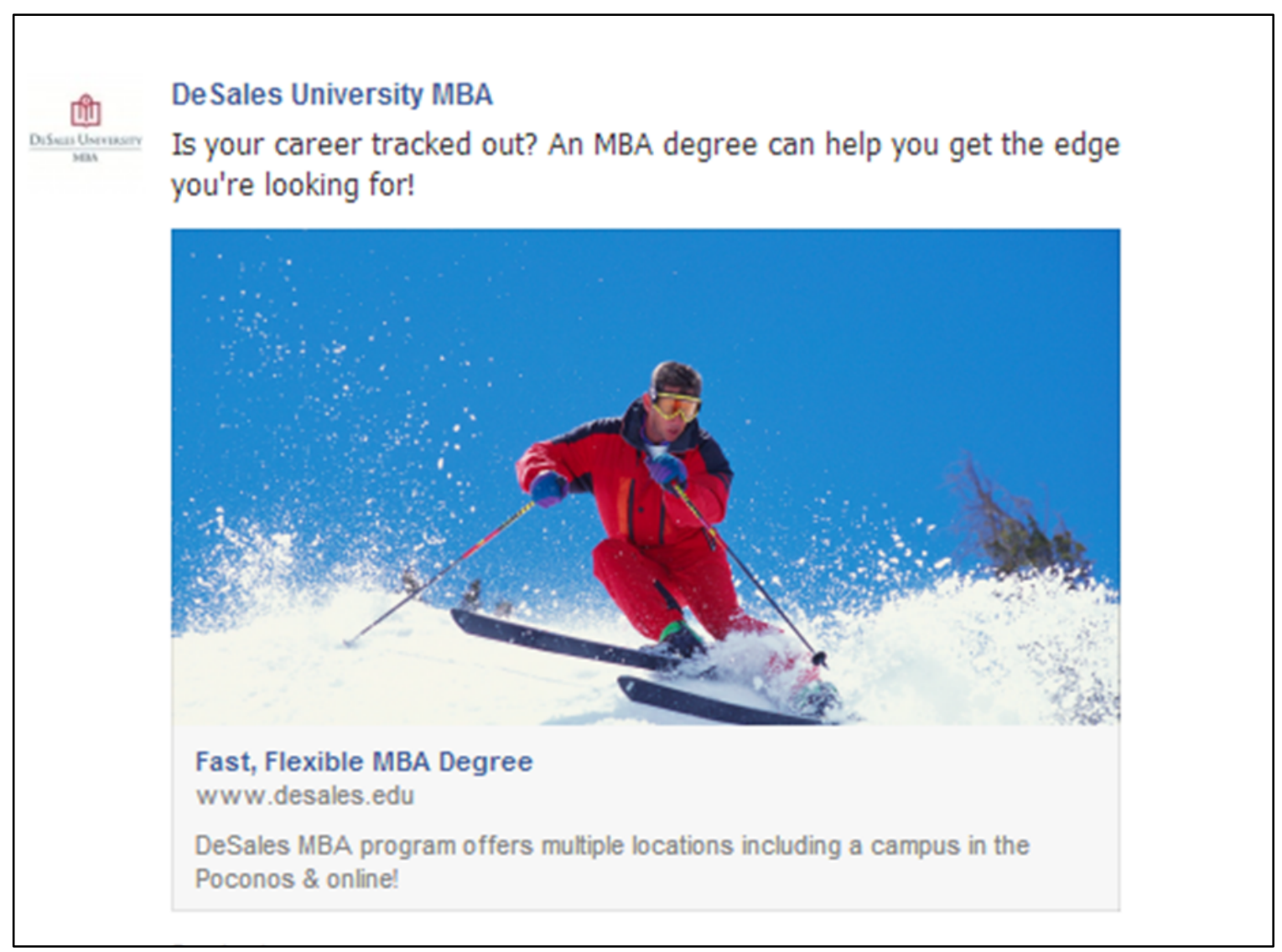

Figure 8: Sample MBA Ad On Facebook

\section{Collect Leads}

Step 6 involves capturing data from prospects who responded in some way to the content that was developed and distributed in step 5. Prospects might have read a blog on the MBA website with insightful Q\&A, seen a LinkedIn pop-up ad, a Facebook ad, or viewed a tweet from an MBA study tour. Having seen these impressions, they could have clicked on a URL, typed in the address to the website, clicked on a QR code, clicked through to a mobile landing page, or called the 1-800 number. In many cases, it is easy to track how the prospect got to the MBA program (i.e. QR code or mobile landing page) and in other cases the prospective customer/student must be asked (1-800 number). If prospective students can be enticed to complete a brief form on a landing page or verbally provide contact information (phone, email, etc.), this information is captured in an MBA database for driving further interaction and/or converting prospects down through the stages of the marketing/sales funnel. 


\section{Evaluate Social Media Effectiveness}

Figure 9 shows an example of how a few pilot social media ad campaigns on LinkedIn were evaluated. The marketing and sales funnel graphic illustrates that the two short term (approximately 2-3 weeks) display ads resulted in 1910 clicks, which drove 22 prospects to the DeSales MBA website. From there, the 22 prospects were called, emailed, or enticed to attend an information session, visit one of our campuses, or directly "apply" online to the program. Seven individuals applied; all of them met the admissions criteria, and were subsequently "admitted" as matriculating MBA students. Approximately 18 months later, these 7 students had generated 26 registrations.

The funnel in Figure 9 reflects a step by step process whereby marketing materials attract targeted prospects (in this case) to click on ads which directs them to the DeSales website and captures their contact information. From there, they either contact the MBA office (via phone, form fill, or email) or are contacted by MBA staff to be "sold" into applying to the program. Staff continue to work the funnel process by engaging applicants until they advance to the next two phases where they are admitted as matriculating MBA students and ultimately register (and pay for) courses.

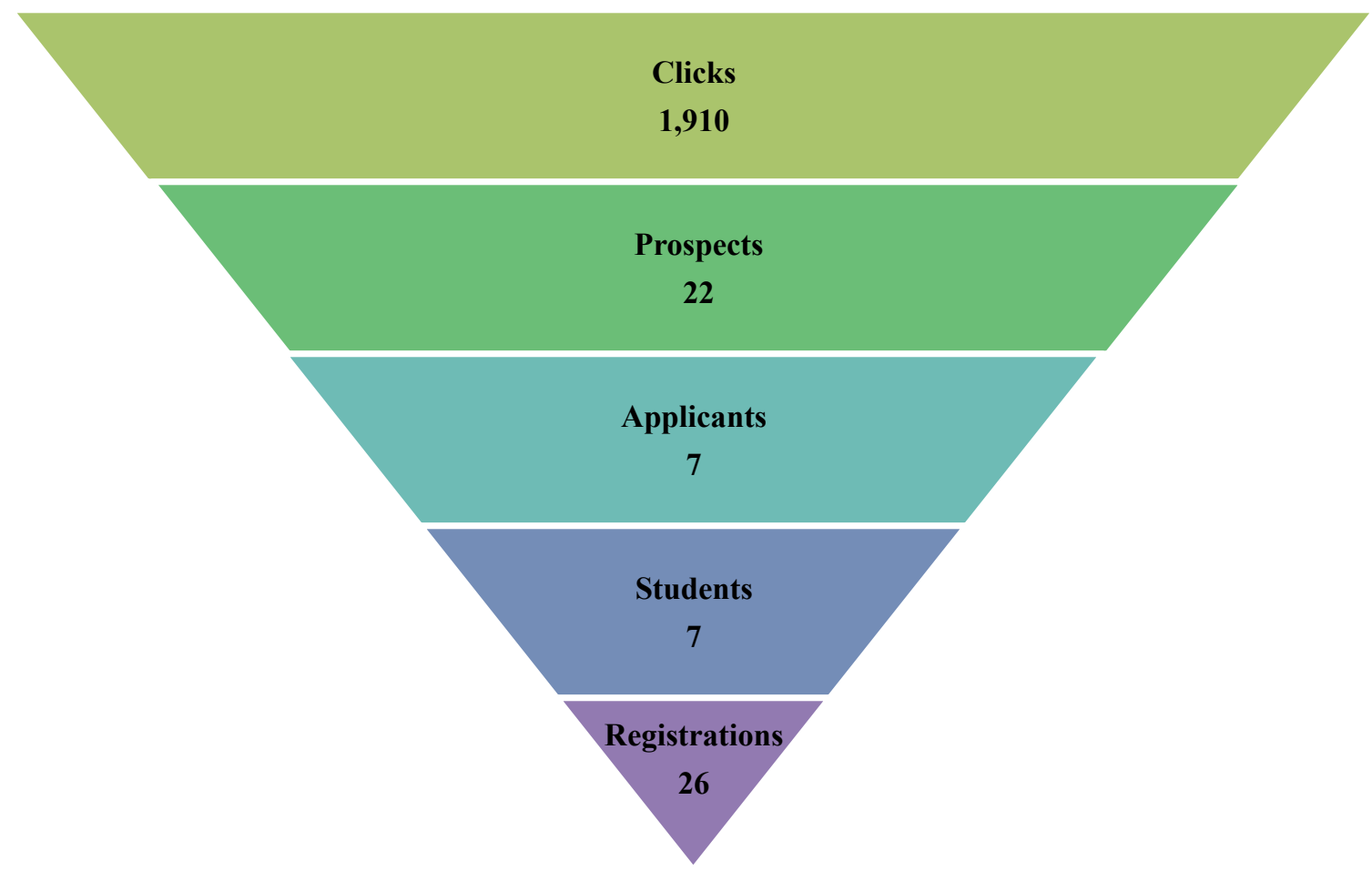

Figure 9: LinkedIn Social Media Ad - Funnel Conversion 


\section{8. $\quad$ Calculate ROI}

Return on investment (ROI) simply refers to the idea that something of value has resulted from an investment of time, energy, or money. In financial circles, ROI usually is reduced to a formula (i.e. Lenskold, 2003; Bragg, 2007):

\section{ROI $=\frac{(\text { Gain from Investment }- \text { Cost of Investment }}{\text { Cost of Investment }}$}

ROI is calculated by simply subtracting the cost of an investment from the proceeds received from the investment, divided by that same investment cost. For example, if you sell a product for $\$ 150$, and the total cost is only $\$ 120$ for the item, then the ROI is (150-120)/120 or $25 \%$. As discussed earlier in this paper, true financial ROI can only be achieved when revenue is realized. In the example above, in Step 7, ROI for the LinkedIn ad would be calculated as:

$\$ 39,312$ (registrations $x$ tuition $x$ profit margin) - $\$ 6,160$ ad spend $\$ 6,160$ ad spend

$\mathrm{ROI}=\$ 37,440-\$ 6,160 / \$ 6,160=538 \%$

Alternatively, Return on Ad Spend (ROAS), which is defined as gross revenue realized for every dollar of ad spend, could be calculated:

$\operatorname{ROAS}=(\$ 62,400 / \$ 6,160)=\$ 10.13$

Other MBA Results

Table 2. Preliminary Ad Spend Results By Social Media Platform

\begin{tabular}{|l|c|c|c|}
\hline & Facebook & LinkedIn & Google \\
\hline ROI & $280 \%$ & $538 \%$ & $897 \%$ \\
\hline ROAS & $\$ 6.33$ & $\$ 10.13$ & $\$ 16.62$ \\
\hline
\end{tabular}

Table 3. Percent Ad Spend Shift - Mba Pilot Study

\begin{tabular}{|l|c|c|c|}
\hline \multicolumn{1}{|c|}{ MBA Session } & \% Traditional & \% Social/Online & $\begin{array}{c}\text { Incremental Ad Shift - } \\
\text { Traditional to Social }\end{array}$ \\
\hline Summer/Fall 2012 & 92 & 8 & $8 \%$ \\
\hline Winter/Spring 2013 & 90 & 10 & $2 \%$ \\
\hline Summer/Fall 2013 & 88 & 12 & $2 \%$ \\
\hline Winter/Spring 2014 & 78 & 22 & $10 \%$ \\
\hline
\end{tabular}

Table 4: Google Organic Search Results For "Lehigh Valley MBA"

\begin{tabular}{|l|c|c|}
\hline \multicolumn{1}{|c|}{ Competitor } & Fall 2012 (Page/Rank) & Spring 2014 (Page/Rank) \\
\hline DeSales University & $1 / 8$ & $1 / 1$ \\
\hline Penn State University & $1 / 7$ & $1 / 9$ \\
\hline Lehigh University & $1 / 1$ & $1 / 2$ \\
\hline Moravian College & $1 / 3$ & $1 / 4$ \\
\hline
\end{tabular}

Table 5. 2014 Social Media Presence By Key Platform By Competitor

\begin{tabular}{|l|c|c|c|}
\hline & Facebook Fans & LinkedIn Members & Twitter Followers \\
\hline DeSales & 2,245 & 563 & 285 \\
\hline Drexel & 2,887 & 1,277 & 2034 \\
\hline Saint Joes & 997 & 832 & 324 \\
\hline Penn State & 4,499 & 56 & 1,781 \\
\hline
\end{tabular}


9.

\section{Adjustments}

The last step in the MBA Social Media Framework involved making adjustments on-the-fly as success metrics and operational outcomes were reviewed each month. Some of the more significant adjustments made during the last 18 months were:

- Decision to replace platforms or adjust platform usage. Flickr was a platform candidate early on because of the visual appeal of photos. It was quickly realized that Twitter held a larger appeal to the program's customer base and the ability to attach photos to tweets was quickly heralded as the best path by customers and prospective customers. In addition, Facebook changed its revenue model mid-stream "free" advertising was initially the norm when content was posted as a newsfeed (tweets, blogs, etc.) to the DeSales MBA Facebook page. Facebook automatically would post this newsfeed to Facebook users who "liked" DeSales MBA. When Facebook started charging for sharing the newsfeed in the past year, alternative, cost-effective sources were explored in order to continue with this source of brand lift although Facebook is still used as a cornerstone platform.

- Decision to adopt new social media platforms. Because of the tremendous popularity of Google, a decision was made to have a presence on Google+, the social networking site, created to compete with Facebook. As of yet, not much value has been seen in this platform, although it is still an active platform for DeSales MBA. From a different perspective, evidence has shown that millennial prospects/customers, are spending more time on Instagram. Since millennials are in the sweet spot of the DeSales MBA target market, a presence has been launched on this platform as well.

- Decision to adopt Pandora internet radio. In the last 12 months, the rise of internet radio became attractive as the costs of terrestrial radio in key markets (i.e. Philadelphia) are fairly prohibitive. Pandora allows user targeting by age, geography, gender and a few other key variables, and the ability to track users who click through to desktop, tablet, and mobile landing pages - at a fraction of the cost of radio. Initial campaigns with Pandora have yielded click through rates (CTR) approaching . $9 \%$ across mobile, tablet, and desktop displays. Increased spend is expected with this platform - especially in the mobile space where the CTR was well above $1 \%$.

\section{DISCUSSION}

The DeSales MBA Social Media pilot journey of 18 months (late Summer 2012 to early Spring 2014) has provided ample opportunity to plan, develop, implement, assess, and partially re-design the program with some valuable insights from social media researchers, pundits, practitioners, and customers (students). Lessons learned and next steps are documented below.

\section{Lessons Learned}

Embarking on a social media journey in a challenging economic environment, with a host of operational and budgetary constraints was a daunting, nevertheless enjoyable, labor for the MBA team. The following casestudy observations/lessons learned are posited:

- Social Media (or some future form of it) is here to stay. The power of eWOM and the geometric brand lift realized as one evolves to social/online media and its potentially endless digital network, is undeniable. The sheer number of "impressions served" and the cost effectiveness of those impressions in the social/online space make it "market sustainable" for years to come. This model clearly works for the MBA marketplace.

- Social Media ROI is measurable, very measurable. If one plans carefully, understands that true financial ROI only happens when a sales conversion takes place in the marketing/sales funnel (most likely at the bottom of the funnel), and knows how to use the right technology (i.e. cookies, tags, landing pages), then the key elements required for success are at hand. In the 18-month pilot study, Social Media and online (Pandora) results were successfully measured. A few false starts and mobile technology (landing page) glitches were experienced, but were ultimately resolved. 
- Content is king. Thinking about the right content is very important - specifically content to which your target market will respond. As a rule, there must be "value add" in the content such as a new way of thinking about getting an MBA, realizing that an MBA can be completed online or that courses will focus on practical tools, methods, procedures that can be applied to the workplace. Content can stimulate a prospective student's desire to travel abroad as part of coursework, or can simply remind the prospect that graduates of a program go on to be very successful in their field of interest. DeSales MBA data has shown that tweets about MBA study tours abroad, MBA alumni "success stories" and external ratings of MBA market share in Pennsylvania are impactful, whereas too many generic "thoughts of the day" can be more annoying than interesting. All content are not created equal - the best content is easy to create, meets some of your prospective customers' needs, and provides a motivational element that drives them to action.

- Understand the big picture (funnel process) first. A typical successful MBA social media initiative begins when program staff understands where and when to reach prospective student customers from the target market. Next, the target market is attracted to initiate some form of contact via digital ad or by providing them with informational content that addresses their current or future needs or interests. Once the prospect contacts the MBA program online or offline for more information, some personal data (email, phone, IP address) is captured that allows tracking of who they are and where they heard of the program. As prospects are successfully "sold" down through the marketing/sales funnel, administrators will be able to automatically track back to see which ads or content yielded which registrations (revenue). If this is executed properly, then the ability to calculate ROI is achieved.

- Enable joint marketing and sales funnel management. Much of the literature reviewed in this paper espouse closer collaboration between marketing and sales in creating a more elaborate set of funnel steps usually referred to as top of funnel (TOFU), middle of funnel (MOFU), and bottom of funnel (BOFU). This collaboration and funnel breakdown can readily be aligned with the processes depicted under "understanding the big picture." Targeted content (i.e. blogs, MBA press releases) drives initial acquisition in TOFU. Engagement (via tweets, contests, blog updates, etc.) and targeted MBA ads on LinkedIn or Facebook in MOFU drive prospects to BOFU where most final sales conversions (phone calls by MBA staff, campus interviews, info sessions) take place. A typical best practice is to "give away" useful content such as research papers or short podcasts, usually in MOFU - once the prospect fills out a short form fill and hits "submit" (referred to as the moral bribe). The form fill enables direct future engagement with the prospect and tracking for future analysis. Several content types and media platforms work well in more than one section of the 3-tiered funnel. The DeSales MBA program is in the process of refining its funnel system to be more closely aligned with TOFU/MOFU/BOFU as an integral part of a more sophisticated ad analytics system. This work will be detailed in a future publication.

- $\quad$ Process, discipline, and ownership (P.D.O.) are not optional. Like most other successful operations in the business world (and yes, an MBA program is a business), process, discipline and ownership are critical. The right set of social media processes must be planned and implemented with the right set of quality, operational, and financial goals in mind. Key tasks must be owned and managed by competent and properly trained employees. Management of a social media program must be built into the fiber of an organization including weekly, monthly, and yearly reviews. Having full-time, dedicated Social Media personnel would greatly help, but sometimes is not practical (DeSales MBA case). Lastly, all key staff and faculty must own social media for it to be successful - starting with the MBA director and direct reports.

- Ad Analytics (Attribution, Optimization \& Allocation) requires more P.D.O. The DeSales MBA program is still at the beginning of the Social Media journey which is actually transforming into a "Big Data" journey. You don't have to be a mega-corporation to use advertising analytics as espoused by Nichols (2013) and practiced by the data analytics and marketing consulting houses and agencies. You do, however, have to have the right processes, discipline, and ownership in place to gather the right internal (i.e. channel revenues, funnel conversion rates) and external (i.e. competitor, economic) data to be able to attribute marketing success to the right media, optimize the right timing and ad mix, and finally allocate marketing resources more effectively. The DeSales MBA program understands the value of tracking and analyzing ad effectiveness data and investing a limited marketing budget in the most effective channels. DeSales MBA will continue to measure ROI in the "swim lanes" and re-allocate from traditional to digital media. The DeSales program will also get more aggressive at tagging prospect media touch points to improve our attribution models and be able to better work with third parties to this end. 
- $\quad$ Pick the right platforms; blend online and offline media. Embrace the platforms that your target audience uses. The typical DeSales MBA student is a middle class, working professional, in their mid to upper 30s, with at least an undergraduate degree. It is most effective to select the right Social Media platforms or tailored (company or industry) ads that reach those select markets where they spend time in cyberspace. LinkedIn and Pandora are solid choices, while Snapchat and Flickr are probably not the best channels. The DeSales MBA Social Media Survey along with published guides to social media helped guide the selection process. DeSales MBA recently targeted a specific healthcare company in a specific geography and served up MBA ads when employees signed in to LinkedIn - the ads reminded them that they could get an MBA by driving or walking to our satellite campus in under five (5) minutes after work. Pandora internet radio was also recently employed because of the platform's ability to serve up tailored audio-visual messages to target listeners by age, gender, and geography relevant to the MBA program. In addition, Pandora enabled the program to focus on the growing population of mobile users in addition to laptop/tablet, and desktop users. Finally, research has shown the benefits of blending offline and online media (i.e. Nielsen \& IAB, 2012). The DeSales MBA program has effectively used billboards, mall posters or various print media to allow for the use of QR codes, for example, that can be captured by QR reader "apps" to quickly re-direct the user to the MBA website along with the ability to track the source to measure ad effectiveness.

- Celebrate successes. Mastering social media implementation and measurement and constantly finding the right blend of traditional and social media into a cost-effective, integrated marketing communications program can seem like a daunting challenge most of the time. It's important to recognize individuals and give the social media team credit for big and small wins alike - a heavily "liked" Facebook blog, an off the charts click through rate from a Pandora ad, dozens of "re-tweets" of a special event, etc. Review them, share the success metrics, and celebrate the people and process ownership that made them happen. Use that energy to drive forward to the next initiative.

\section{Next Steps}

While the DeSales MBA Social Media pilot program was a success from several vantage points, there is still much to learn - and the marketing landscape is evolving rapidly. Next steps have been prioritized as follows:

- $\quad$ Capture the gains. DeSales MBA is committed to building on the initial pilot success by reviewing and streamlining all social media platforms and processes. What works well (as measured by platform performance metrics such as Google Analytics, Klout or Tweetreach) will be kept, but experiments will be conducted with newer platforms or formats (i.e. Instagram, Pandora). Well suited social media task management assignments will be kept intact, but expansion or incorporation of other tasks and/or other MBA staff will be considered. Popular (strong performing) content categories will be continued, but the program will be open to content creation ideas from the existing MBA customer base and/or target markets.

- Further refine and operationalize our marketing and sales funnel. In keeping with the concept of an integrated marketing and sales funnel with three (3) distinct sections (TOFU, MOFU, BOFU), DeSales MBA will apply this concept to the current model, ensuring that the right metrics are in place at each stage to track and manage progress. DeSales MBA will develop, through staff training, a new sense of rigor and discipline around this prioritization and measurement of key analytics. The goal is to identify 3-5 measurable actions a prospective MBA student might take on the MBA website or other social media touch points that can be tied to the prospect's digital cookies. In addition to the cookie integration, independent measurable touch-points on each of the swim-lanes (that mean something in our funnel stages) will be captured. Finally, DeSales MBA must develop a method to consistently capture each prospect's digital information when they call or visit the MBA office in person so that this information can be used for subsequent analysis and synchronization with other data.

- Adapt a more aggressive ad spend shift from traditional to social/online media platforms. The "next steps" articulated above are designed to bring the DeSales MBA social media program, longer term, to where it can be fully immersed in advertising analytics. In the interim, research and current pilot study data strongly suggest that a greater portion of the MBA ad budget should be shifted away from the more expensive traditional ad platforms, to at least a $25-35 \%$ online share of total spend. Time and money will be invested, for example, on the development of YouTube video ads called "TrueView" that give viewers 
choice and control over which ad they watch and when. The MBA program would only be charged when a viewer has chosen to watch the ad.

\section{CONCLUSION}

This paper has attempted to underscore the importance of social media platforms as viable marketing and sales tools to help businesses grow and prosper. It has also attempted to address and discuss the two "ROI" issues that have been debated in the literature - "Return on Investment" of social media ad spend and "Re-allocation of Investment (ad spend) from traditional to social/digital media. Next, the paper has endeavored to briefly discuss and tie in the concepts of big data, advertising analytics, and integrated marketing and sales funnels as they relate to practical applications of social media programs in the "real world". A case study involving the development and application of an MBA social media pilot program for a large northeast Pennsylvania university was also presented and explained in some detail.

Key takeaways from the case study confirm that social media can readily be measured, provide ROI support for social media as effective advertising platforms, and suggest that a more aggressive ratio of social to total ad spend mix $(20+\%)$ is not an unreasonable idea. Additional takeaways suggest that process, discipline, and ownership are critical to ensure success of such a program, including the need to have some level of "dedicated" social media support as well as active engagement by all MBA faculty and staff. Perhaps most importantly, for the DeSales MBA program, key takeaways also call for a more integrated marketing and sales funnel management system - incorporating key funnel metrics at top, middle, and bottom levels. Such funnel metrics can readily be fed into a more comprehensive ad analytics system which will allow DeSales MBA to attribute, optimize, and reallocate elements of our integrated marketing communications. These ideas are currently being implemented and will be further disclosed in future publications.

\section{AUTHOR INFORMATION}

David M. Gilfoil, Ph.D., is Associate Professor of Business and Director of the DeSales University MBA Program in Center Valley, Pennsylvania, USA. He holds a B.A. degree in psychology from the University of Massachusetts, an M.A. in cognitive/experimental psychology from the College of William and Mary in Virginia, and a Ph.D. in Management Science from Stevens Institute of Technology in NJ. His research interests are measures of global competency, global business ethics, and marketing \& sales tools, processes and procedures, as well as quality issues in healthcare. Email: david.gilfoil@,desales.edu

Steven M. Aukers, Ph.D. is Assistant Professor of Business in the Division of Business, DeSales University in Center Valley Pennsylvania, USA. He holds a B.A. degree in Telecommunications and Marketing, an M.S. in Sports/Recreation Administration, and a Ph.D. in Human Performance with a focus on Marketing and Consumer Behavior from Indiana University. He served over two decades as a senior executive in industry including chief executive officer roles. His research interests are corporate strategy, leadership, consumer behavior and decision making, and marketing and sales strategy. Email: steven.aukers@,desales.edu

Dr. Charles Jobs serves as an Assistant Professor in the Business Department of DeSales University. Before joining DeSales Dr. Jobs was as full-time professor in the Business School at West Chester University.

Prior to his academic career Dr. Jobs was the General Manager of the SITA Business Unit in North America for France Telecom (Orange). The SITA Business Unit in North America was a $\$ 150$ million per annum business unit. He also held sales management and/or information technology positions at British Telecom (BT), Eastern Telelogic (Comcast), Wyeth Pharmaceuticals and Unisys. He has conducted business in over 25 countries and has spent considerable time overseas during his $20+$ year professional career.

Dr. Jobs received a Ph.D. in International Economic Development from The University of Southern Mississippi, his MBA from Saint Joseph's University, and a BA in Business Computer Science from Bloomsburg University. He has published numerous papers related to social media marketing and big data. His areas of interest include: international business management, sales/marketing strategy, international economic development, information technologies, green technologies and student study abroad programs. 


\section{REFERENCES}

1. Arnold, T., \& Solis, B. (2011). ROI on Social Media. Arts Marketing, 1-10.

2. Awareness (2012). The State of Social Media Marketing. September, 2012. http://info.awarenessnetworks.com/The-State-Of-Social-Media-Marketing.html

3. Bartholomew, D. (2010, May 12). The Digitization of Research and Measurement [Web log post]. Retrieved June 14, 2012, from http://metricsman.wordpress.com/2010/05/12/the-digitization-of-researchand-measurement/

4. Bartholomew, D. (2009, June 4). Measuring Influence in Social Media [Web log post]. Retrieved June 14, 2012, from http://metricsman.wordpress.com/2009/06/04/measuring-influence-in-social-media/

5. Bartholomew, D. (2010, July 19). Don't Let the Tool Tail the Measurement Dog [Web log post]. Retrieved June 14, 2012, from http://metricsman.wordpress.com/2010/07/19/dont-let-the-tool-tail-wag-themeasurement-dog/

6. $\quad$ Blanchard, O. (2011). Social media ROI: Managing and measuring social media efforts in your organization. Pearson Education.

7. Bragg, S. (2007). Business Ratios and Formulas: A Comprehensive Guide. (pp. 123-144). Hoboken, NJ:

8. John Wiley \& Sons, Inc.

9. CMO.com. 2011 http://www.cmo.com/social-media/2011-cmos-guide-social-landscape\#ixzz1WQnhtWZI

10. Constantinides, E., Romero, C. L., \& Boria, M. A. G. (2009). Social media: a new frontier for retailers?. In European Retail Research (pp. 1-28). Gabler.

11. eMarketer (2012). Marketers Still Can't Tie Social to Bottom Line. September 12, 2012. http://www.emarketer.com/Article.aspx?R=1009340\&ecid=a6506033675d47f881651943c21c5ed4.

12. Fisher, T. (2009). ROI in social media: A look at the arguments. Journal of Database Marketing \& Customer Strategy Management, 16(3), 189-195.

13. Gartner (2010). User Survey Analysis: Consumer Marketing Using Social Network Analysis, Worldwide, 2010. http://www.gartner.com/it/page.jsp?id=1409213

14. Gilfoil, D. M., \& Jobs, C. G. (2011). Mind the Gap: A Global Analysis of the Number of Buyers to Sellers Using Blogging, Social Networking, Online Video, and Microblogging Platforms. International Journal of Business Research, 11(5).

15. Gilfoil, D. M., \& Jobs, C. (2012). Return on Investment For Social Media: A Proposed Framework For Understanding, Implementing, And Measuring The Return. Journal of Business \& Economics Research (JBER), 10(11), 637-650.

16. Hartline, J., Mirrokni, V., \& Sundararajan, M. (2008, April). Optimal marketing strategies over social networks. In Proceedings of the 17th international conference on World Wide Web (pp. 189-198). ACM.

17. Jalilvand, M. R., Esfahani, S. S., \& Samiei, N. (2011). Electronic word-of-mouth: Challenges and opportunities. Procedia Computer Science, 3, 42-46.

18. Jansen, B. J., Zhang, M., Sobel, K., \& Chowdury, A. (2009). Twitter power: Tweets as electronic word of mouth. Journal of the American society for information science and technology, 60(11), 2169-2188.

19. Jobs, C. (2012). A Comparative Analysis of the Adoption Rates of Social Networking and Microblogging Between Industrialized and Developing Nations. Journal of International Business Research, 11(1).

20. Jobs, C., and Gilfoil, D. (2014). A Social Media Advertising Adoption Model for Reallocation of Traditional Advertising Budgets. Accepted for Publication by Academy of Marketing Studies Journal,

21. September 2, 2013.

22. Keenan, J. (2013). Social Selling Increases Sales Revenue. http://asalesguy.com/2013/03/26/report-socialselling-increases-sales

23. Kelly, N. (2012). How to Measure Social Media: A Step-By-Step Guide to Developing and Assessing Social Media ROI. Que Publishing.

24. Lenskold, J. (2003). Marketing ROI: the path to campaign, customer, and corporate profitability. McGrawHill Professional.

25. Leskovec, J., Adamic, L. A., \& Huberman, B. A. (2007). The dynamics of viral marketing. ACM Transactions on the Web (TWEB), 1(1), 5.

26. Lohr, S. (2012). The age of big data. New York Times, 11.

27. McAfee, A., Brynjolfsson, E., Davenport, T. H., Patil, D. J., \& Barton, D. (2012). Big Data. The management revolution. Harvard Bus Rev, 90(10), 61-67. 
28. Moran, G. (2014). Four Social Selling Success Strategies for Your Sales Playbook. http://marketingthink.com/four-social-selling-success-strategies-for-your-sales-playbook

29. Murdough, C. (2009). Social media measurement: It's not impossible. Journal of Interactive Advertising, 10(1), 94-99.

30. Nair, M. (2011). Understanding and measuring the value of social media. Journal of Corporate Accounting \& Finance, 22(3), 45-51.

31. Nichols, W. (2013). Advertising Analytics 2.0. Harvard Business Review, 91(3), 60-68.

32. Nielsen \& IAB (2012). A Comprehensive Picture of Digital Video and TV Advertising: Viewing, Budget Share Shift and Effectiveness. Nielsen/IAB. Retrieved March 21, 2013, from http://www.iab.net/media/file/Digital-Video-and-TV-Advertising-Viewing-Budget-Share-Shift-andEffectiveness-FINAL.pdf

33. Piskorski, M., \& McCall, T. (2010). Vision Statement: Mapping the Social Internet. Harvard Business Review, 88 (7-8).

34. Powell, G., Groves, S., \& Dimos, J. (2011). ROI of Social Media: How to improve the return on your social marketing investment. John Wiley \& Sons.

35. Ray, A. (2010, July 19). The ROI Of Social Media Marketing: More Than Dollars And Cents [Web log post]. Retrieved June 14, 2012, from http://blogs.forrester.com/augie ray/10-07-19roi social media marketing more dollars and cents

36. Rogers, E. (2003, 1995, 1983, 1971, 1962). Diffusion of Innovations, 5th ed. (2003). New York: NY: Simon and Shuster.

37. Rosenberg, J. (2013). Leveraging Funnel Metrics Inside of Salesforce to Drive Sales and Marketing Alignment. The Full Circle CRM Blog, July 9, 2013.

38. Solis, B. (2008). The Essential Guide to Social Media - A Free eBook. Retrieved from http:/www.briansolis.com/2008/06/essential-guide-to-social-media-free/

39. Solis, B. (2010). Engage: The complete guide for brands and businesses to build, cultivate, and measure success in the new web. John Wiley \& Sons.

40. Van der Lans, R., Van Bruggen, G., Eliashberg, J., \& Wierenga, B. (2010). A viral branching model for predicting the spread of electronic word of mouth. Marketing Science, 29(2), 348-365.

41. Viskovich, J. (2013). Social Selling: The New Practitioners Guide. Feb. 2013 http://socialmediatoday.com/juliovisko/1247371/new-practitioners-guide 